$$
\text { مقايسه شكل بدن كيور سر گنده و ريخت }
$$

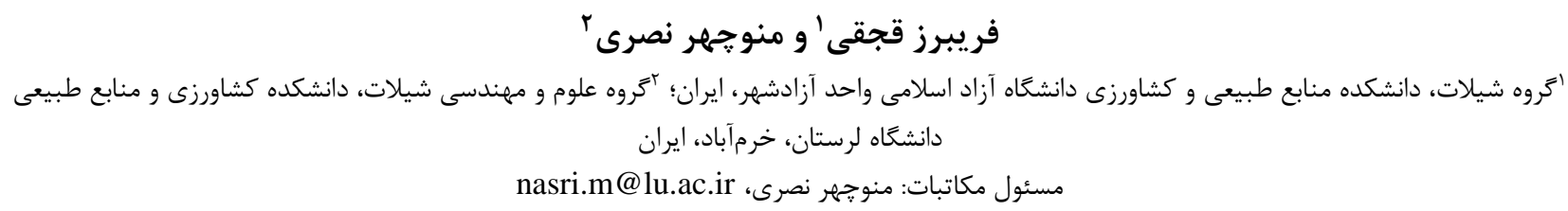

קكيده. بلمنظور بررسى تفاوتهاى شكلى كيور سركنده و دو ريخت كروه معروف از ماهى هاى فيتوفاك با استفاده از تكنيك ريختسنجى هندسى، تعداد • ب قطعه

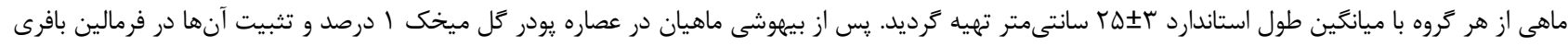

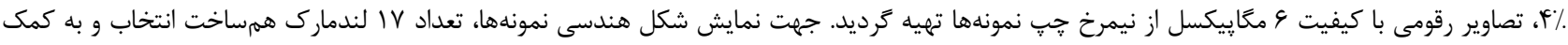

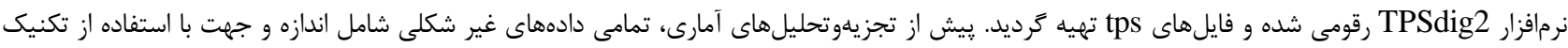

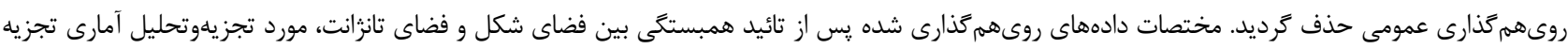

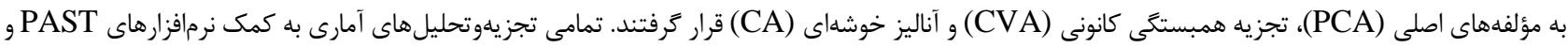

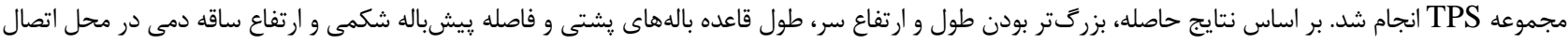

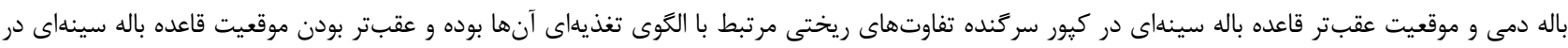

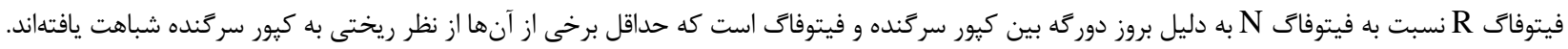

$$
\text { كلمات كليدى. تكثير مصنوعى ماهيان، دور كَ كَيرى در ماهيان، ريختشناسى، كيورماهيان خينى، ماهيان كَمابى }
$$

\title{
Body shape comparison of Big-head carp with two variants of silver carp using geometric morphometric techniques
}

\author{
Fariborz Ghojoghi ${ }^{1} \&$ Manoochehr Nasri $^{2}$ \\ ${ }^{1}$ Department of Fisheries, Faculty of Natural Resources, University of Islamic Azad University, Azadshahr Branch, \\ Azadshahr, Iran; ${ }^{2}$ Department of Fisheries Science and Engineering, Faculty of Agriculture and Natural Resources, \\ Lorestan University, Khorramabad, Iran \\ Correspondent author: Manoochehr Nasri, nasri.m@lu.ac.ir
}

\begin{abstract}
In order to investigate the differences in the shape of the big-head and two morphotypes of Phytophagous fish by geometric morphometric technique, 30 samples of each group, with a mean standard length of $25 \pm 3 \mathrm{~cm}$, were prepared. After fish were anesthetized by $1 \%$ Clove powder extract and stabilized in formalin buffer 4\%, 6-megapixel digital images of the left profile of the specimens were prepared. A total of 17 morphological landmarks were digitized by tpsDig2 software and the tps files were prepared. All non-shaped data were removed from landmark coordinates by generalized procrustes analysis. After the approval of regression between shape space and tangent space, data were analyzed using Principal Component (PCA), Canonical Variation (CVA) and Cluster Analyzes (CA) methods in PAST and TPS series. According to the results, the head length and height, the size of dorsal fin, the length of pre ventral distance, the height of caudal peduncle and the degree of posterior position of the pectoral fin in bighead carp, are some of the distinctive morphological features among species, mainly related to their ecological niche (specially feeding strategies). In the case of silver carp variants, the posterior position of pectoral fin base in silver carp-R that is close to bighead carp, may be due to hybridization between bighead carp and silver carps.
\end{abstract}

Keywords. artificial fish reproduction, Chinese carps, fish hybridization, morphology, warm water fishes. 
منابع آبى جهان معرفى شدهاند (Coad, 2018). مههترين صفات

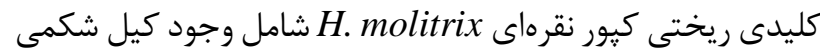

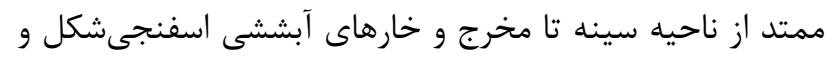
در مورد كيور سركنده Hobilis شامل عبور باله سينهاى از قاعده باله مخرجى، كيل شكمى كوتاه حدفاصل باله شكمى تا داله مخرج و وجود خارهاى آبششى واضح قابل شناسايى هستند

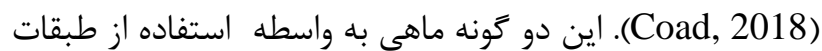
Coad, ) بايين هرم غذايى از نظر هزينه توليد مقرونبهصرفه بونه 2018; Froese \& Pauly, 2019 از توليد ماهيان گرمآبى را به خود اختصاص مي عدهند. اولين كزارش از دوركه كيرى بين دو كونه كيور سركنده و كيور

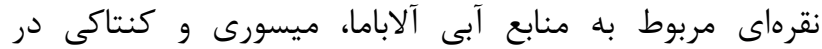

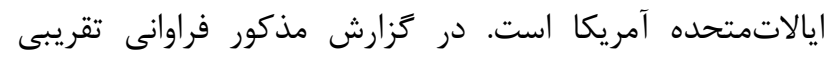

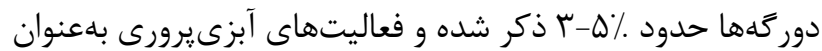

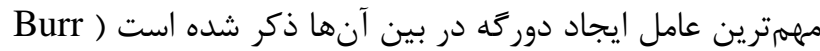
آ آلوزايم تشخيصى نشان داده كه فراوانى دوركه كَيرى بين دو گَونه

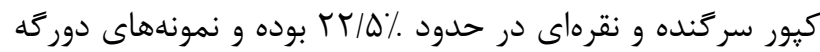

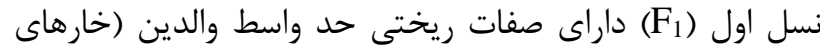

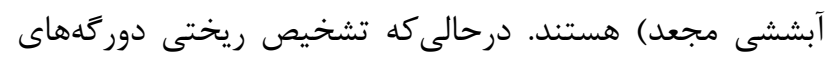
يس از نسل اول (post-F1) از نظر ريختى دشوار است ( Lamer) et al., 2011

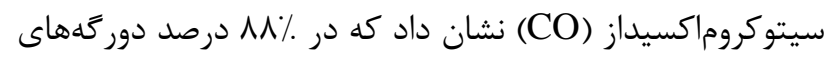

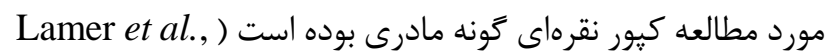
2011). با توجه به همريوشانى آشيان بومشناختى اين دو كونه،

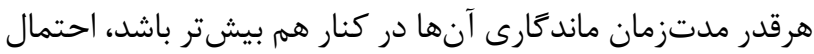

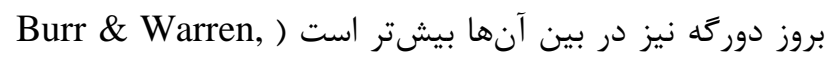

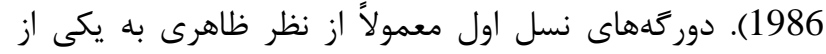

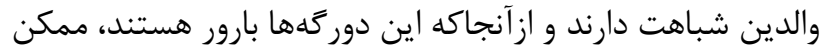
است نمونههايى از نسل دوم نيز در بين جمعيت يافت شود (Conover et al., 2007; Neeley, 2016) همانطور كه از مطالعات مختلف برمى آيد، درصد بروز دوركه بين دو گونه كيور سركنده و كيور نقرهاى بالا بوده و نمونهای

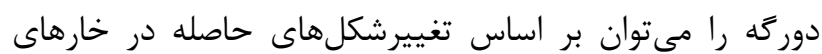

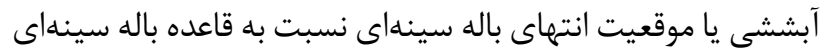
تا حدودى تشخيص داد. مطالعه حاضر بلمنظور سنجش فرض

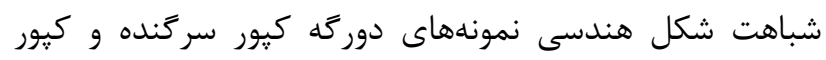
نقرهاى با كونهاى والدينى طراحى و پِيادهسازى ترديد. نتايج اين مطالعه مىتواند در مطالعات مديريتى در تكثير و يرورش ماهيان كرمآبى مفيد باشد.
مقلهمه

در سالهاى اخير مطالعات متعددى در رابطه با الكَوهاى ريختى

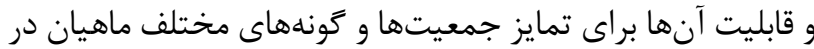

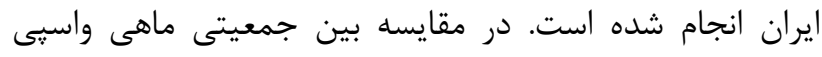
Cabdio morar (Hamilton, 1822) هندسى وجود تنوع درونَونهاى براى اين ماهى كزارش شد

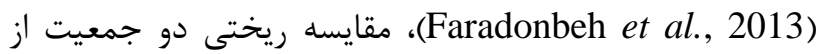
ماهى خياطه در حوضه جنوبى درياى خزر بر اساس شبكه تراس هيج تفاوت معنىدارى بين جنسهاى نر و ماده نشان نداد اما مشخص كرد كه جمعيتهاى مختلف اين ماهى از نظر ريختى قابل تمايز هستند (Haghighi et al., 2012). در مطالعه تغييرات شكل بدن در جمعيتهاى مختلف ماهى خياطه، وجود قابليت

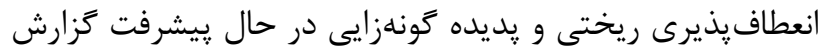
كرديد (Eagderi et al., 2013). مطالعه تنوع ريختى شاهو كولى دانى در سواحل جنوبى درياى خزر نشان داد جمعيتهاى ساكن

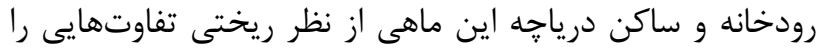

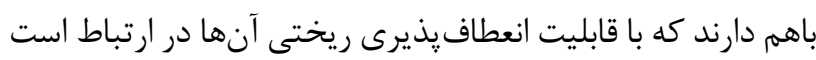
ماه (Mohadasi et al., 2014) ماهى سبزوى Cyprinion watsoni (Day, 1872) در ايران

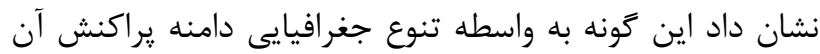

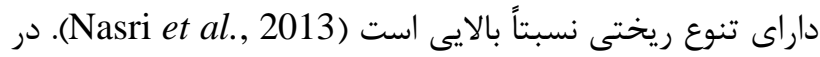
رابطه با كاربردهاى ريختسنجى هندسى در در مطالعات ماهيان جهان نيز مىتوان به مطالعه ريختسنجى هندسى سر إنى مارماهىشكلان (Eagderi \& Adriaens, 2010)، مطالعه تغييرات شكل بدن ماهى باس دريايى در پاسخ به ماسه محركهاى محيطى (Costa et al., 2010)، مطالعه اشتقاق ريختى داستى

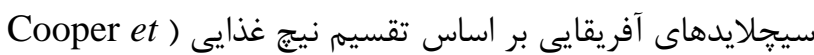

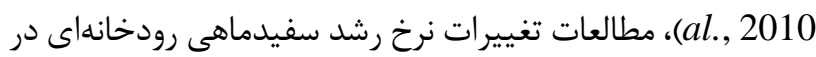

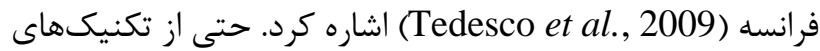
ريختسنجى هندسى در مطالعه و شناسايى جمعيتهاى مختلف

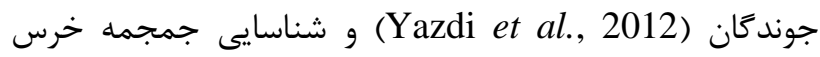
قهوهاى ايرانى (Ghanbari et al., 2013) نيز استفاده شده است. بنابراين قابليت اين روشها براى تمايز ريختى جمعيتهاى مختلف

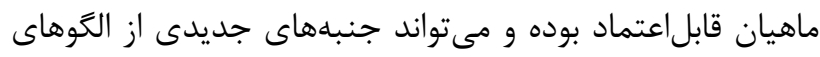

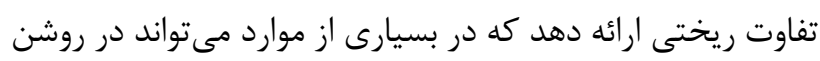
شدن برخى جنبههاى زيستشناسى ماهيان مفيد باشد. ماهى جنس Hypophthalmichthys Bleeker, 1859 باس سه كونه تائيد شده اصالتاً متعلق به شرق آسيا (كشورهاى جين و و روسيه) بوده و از ميان آنها دو كونه كيور نقرهاى و كيور سركنده

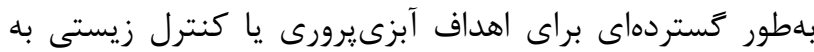


لندماركهاى استفاده شده بود (شكل T). بر اساس مقادير بار

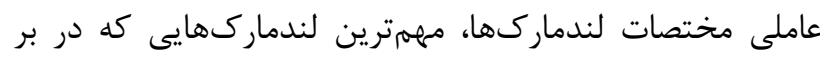

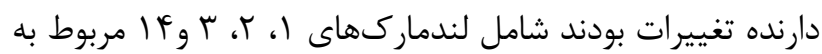

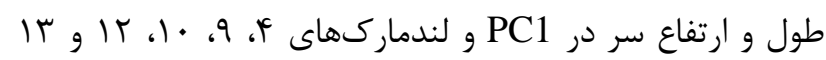

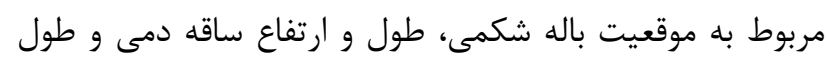

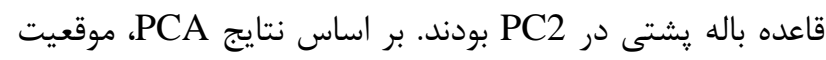

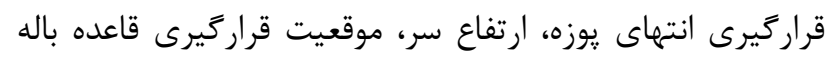

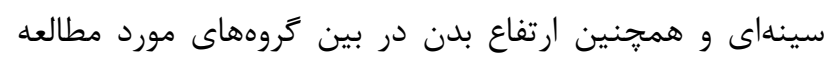

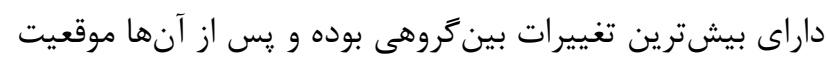

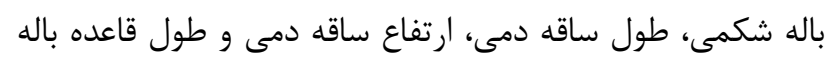

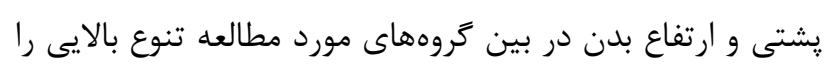

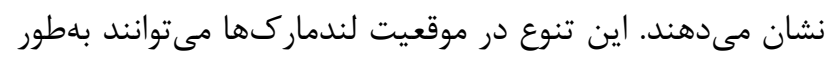

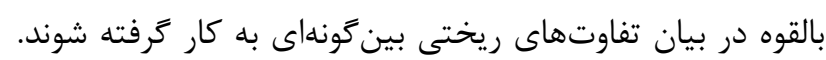

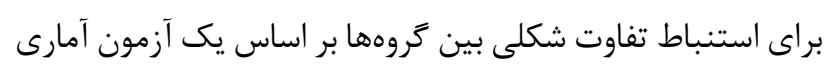

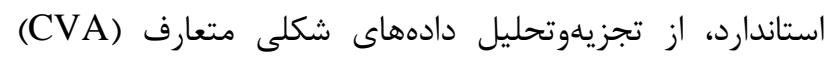

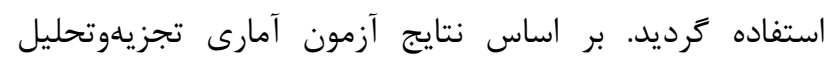

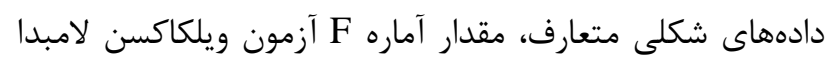

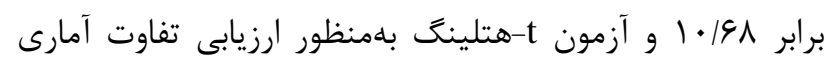

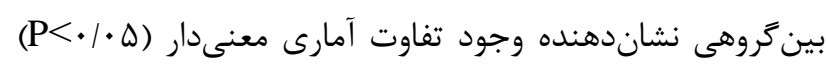

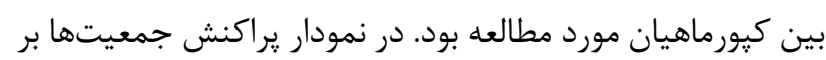
اساس دو CV اول و دوم مشخص است كه كونه كيور سركنده

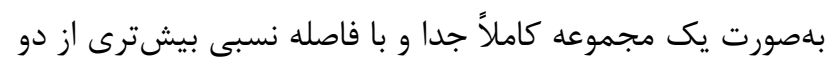

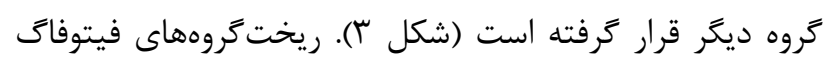

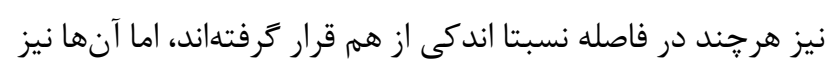

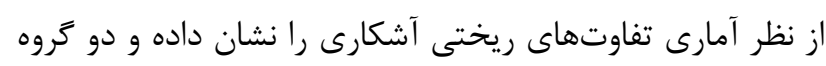

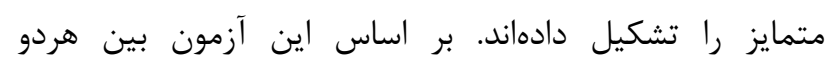

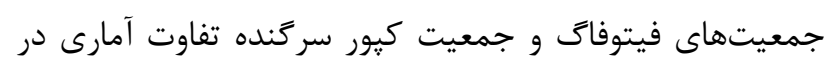

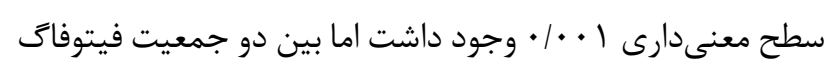

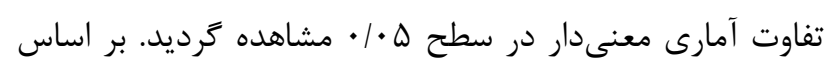

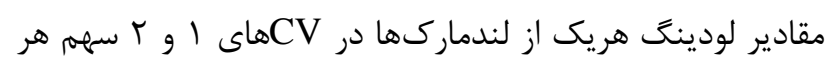

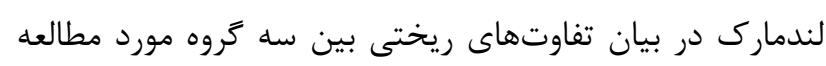

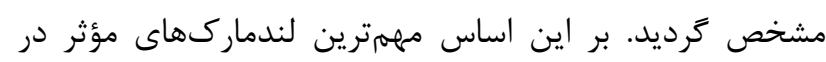

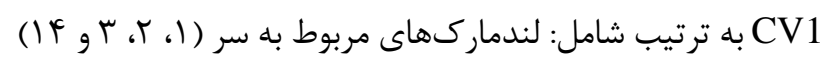

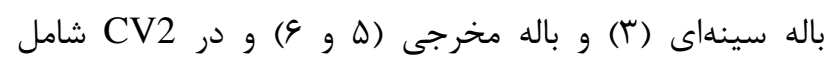

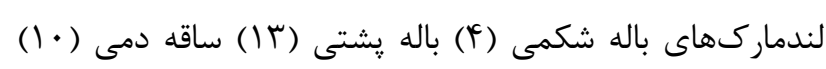

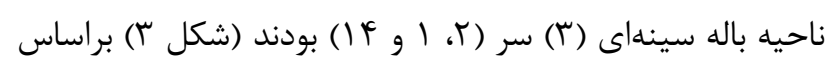

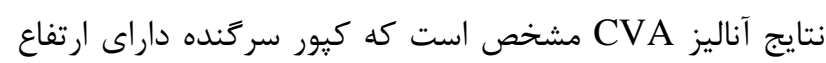

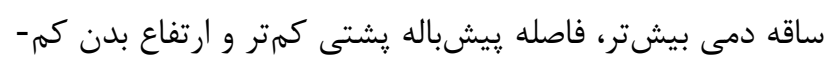

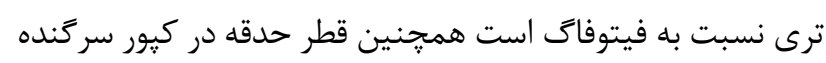
كمتر بوده و حدقه در كيور سركنده در موقعيت پايينترى

\section{مواد و روشها}

در اين مطالعه گَونه كيور سر گنده و دو دو ريخت

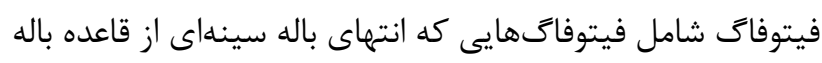

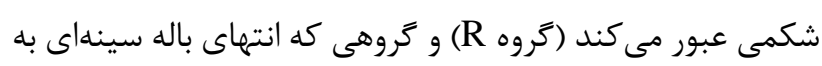

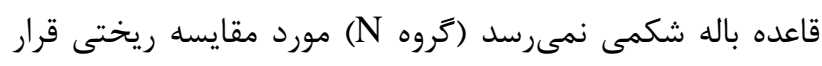

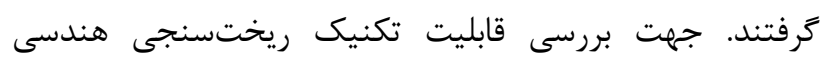

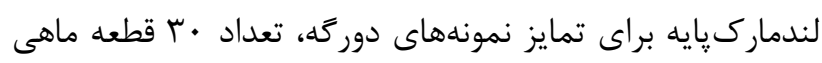

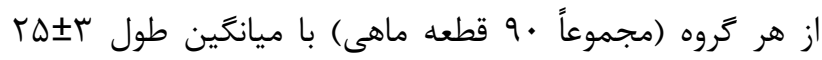

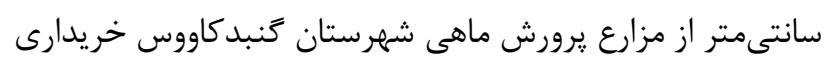

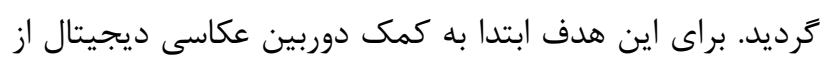

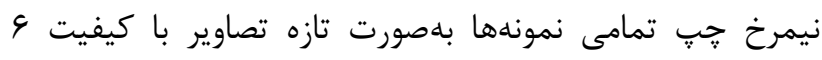

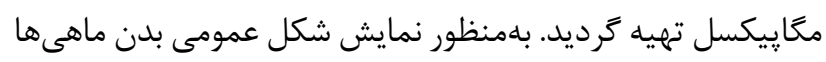

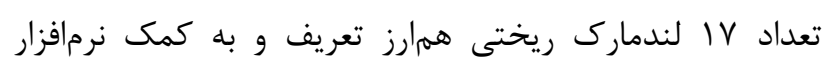

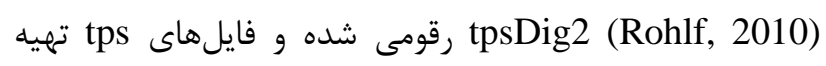

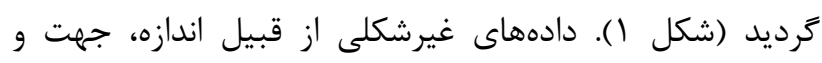

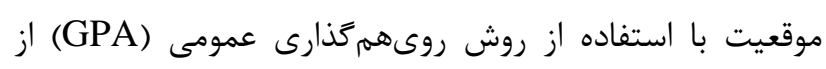

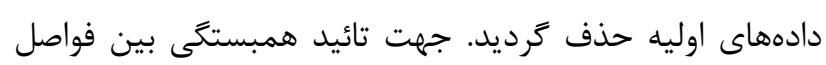
يروكراست در فضاى شكل و فواصل اقليدسى در فضاى تردئ تانزانت،

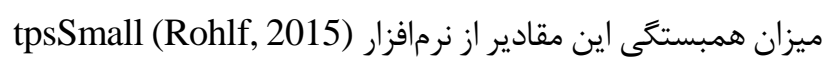

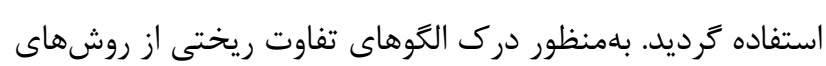

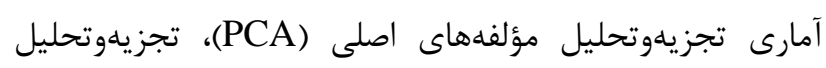

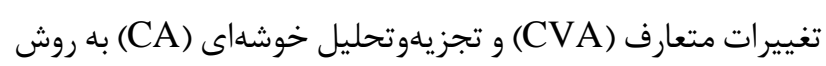

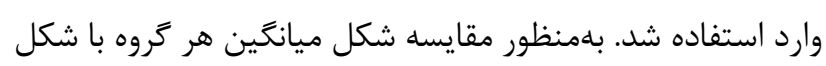

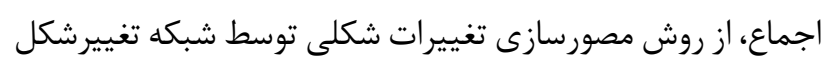

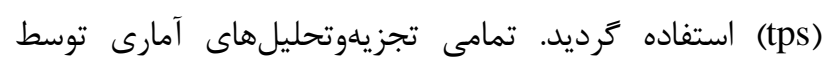

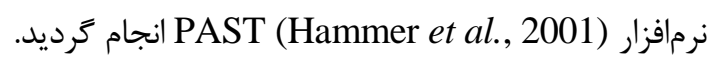

\section{نتايج}

نتايج همبستگى بين فواصل يروكراست و فواصل اقليدسى يا

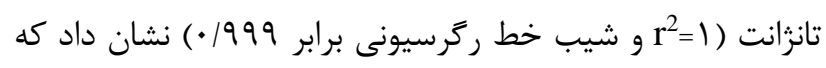

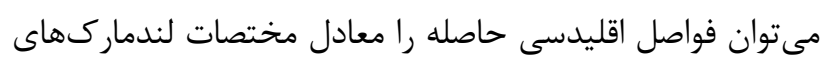

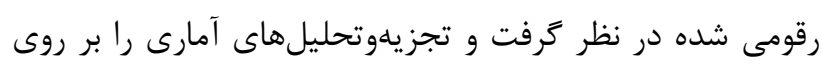

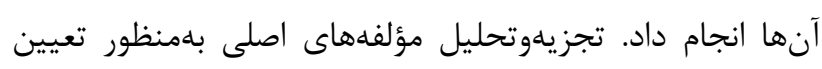

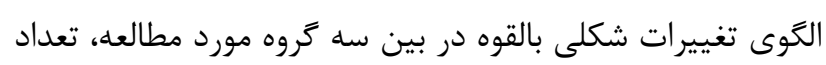

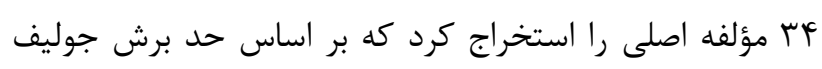
برابر (Jolliffe Cut-Off)

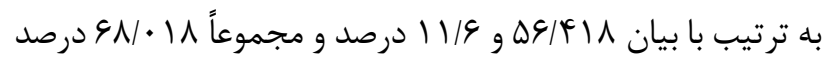

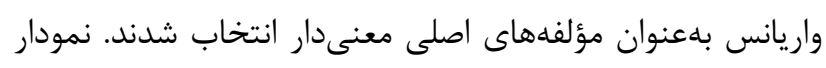

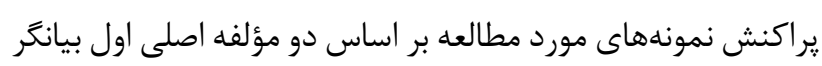

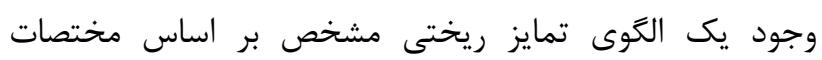




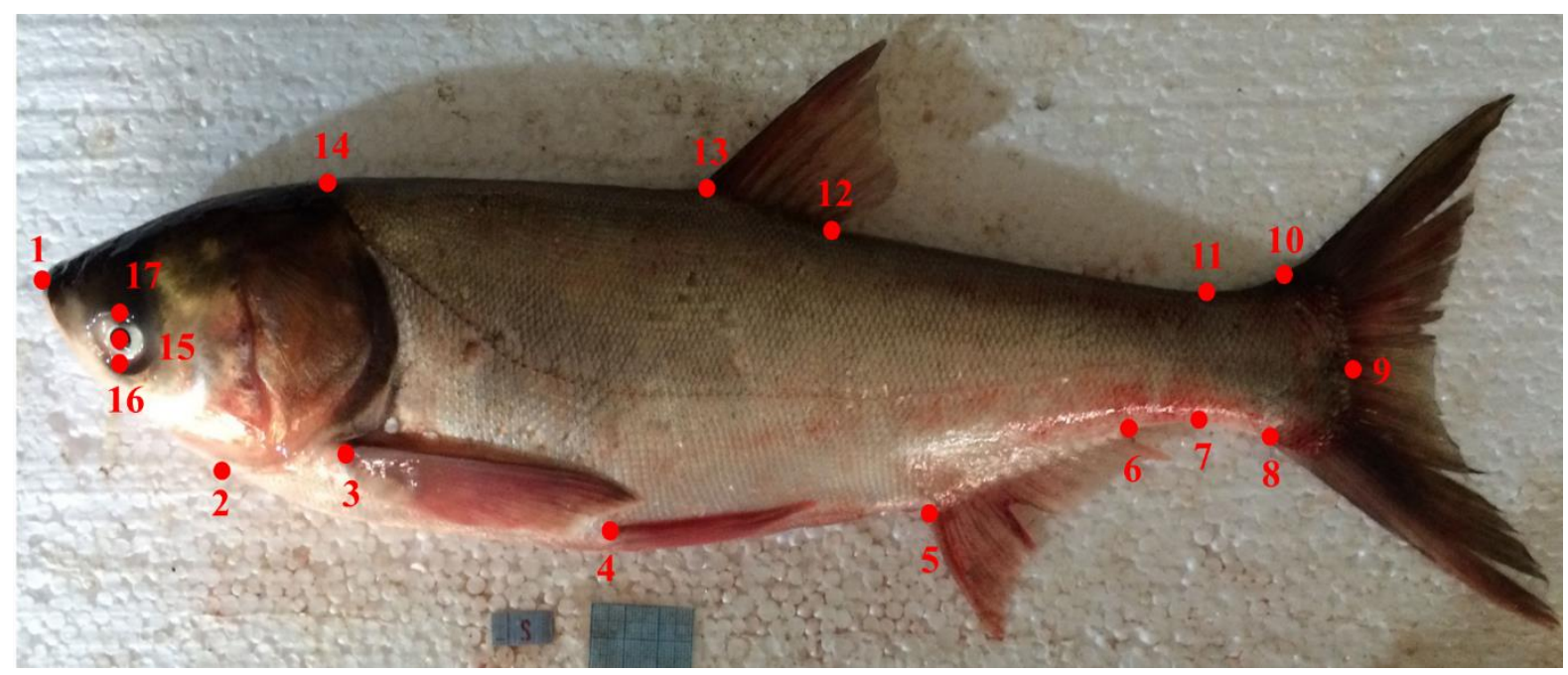

شكل ا- نمايش موقعيت و تعريف لندماركهاى استفاده شده جهت مقايسه شكل هندسى (تصوير مربوط به كيور نقرهاى است). ا- ابتدايىترين بخش فكى بالا،

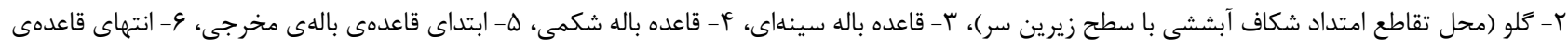

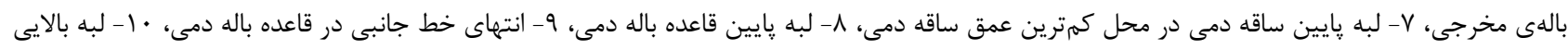

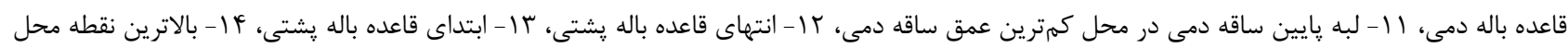

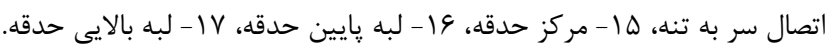

Fig. 1. Seventeen defined landmarks on the left side of specimens. 1: the anterior-most point on the head, 2: the lower corner of opercular opening, 3: the outer edge of pectoral fin base, 4: the base of pelvic fin, 5: the front base of anal fin, 6: the posterior base of anal fin, 7: the lower margin at the narrowest point of caudal peduncle, 8: the lower edge of caudal fin base, 9: the most distant point of lateral line at the base of caudal fin, 10: the upper edge of caudal fin base, 11: the upper margin at the narrowest point of caudal peduncle, 12: the posterior edge of dorsal fin base, 13: the front edge of dorsal fin base, 14: the junction of the head and trunk, 15: the center of orbital, 16: the lower margin of orbital, 17: the upper margin of orbital.

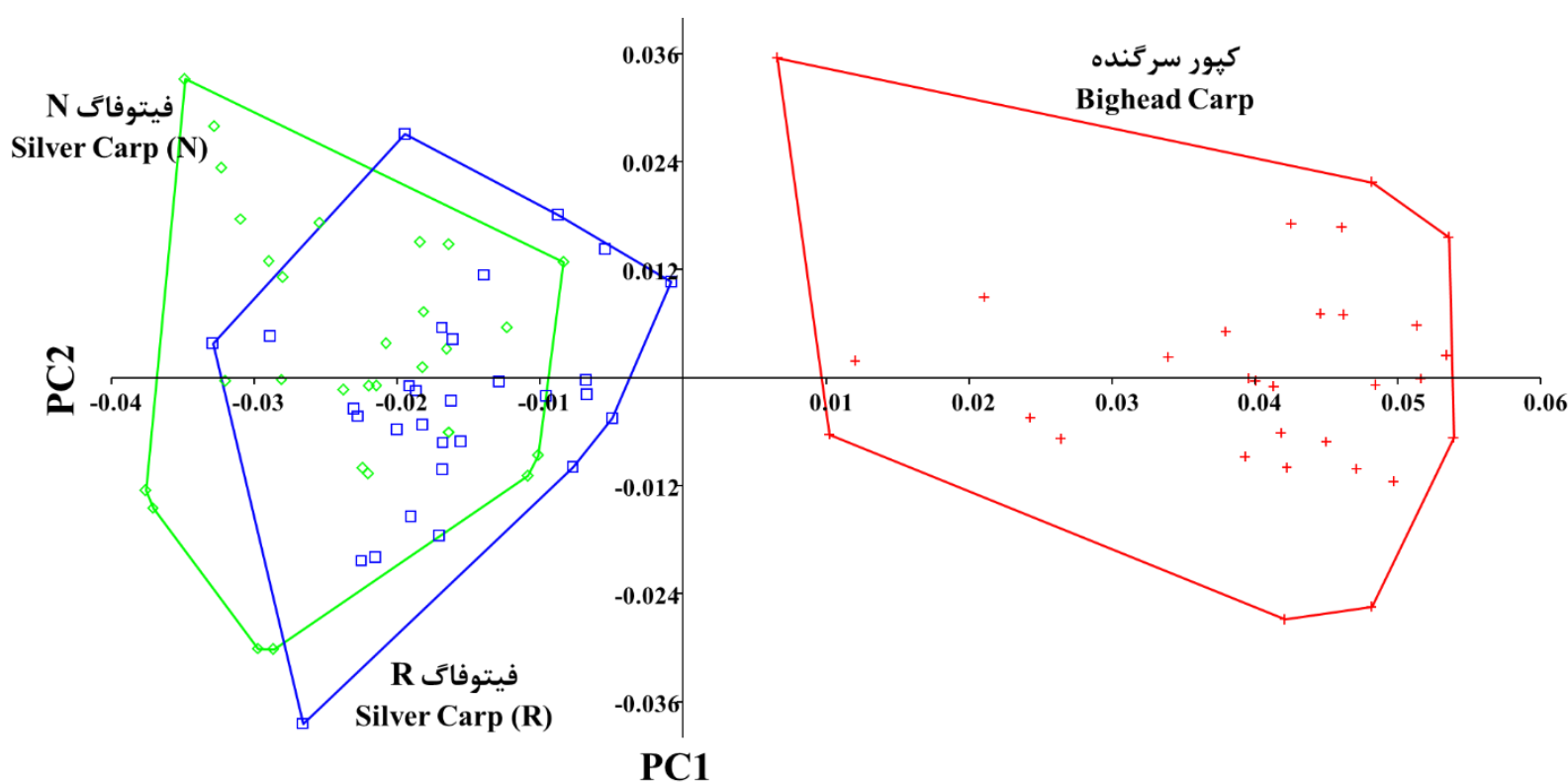

شكل r- نمودار يراكنش نمونه هاى مورد مطالعه بر اساس دو مؤلفه اصلى اول.

Fig. 2. Scatterplot of the specimens based on the first two principal components. 
هستند و فلسهاى ريز سطح بدن را يوشاندهاند. كيور سركنده

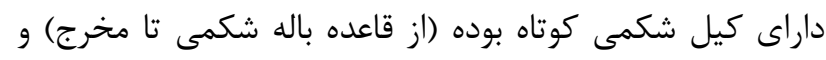
انتهاى باله سينهاى آن از قاعدى باده باله شكمى عبور مى كند (Abdoli, 2000; Coad, 2018; Froese \& Pauly, 2019)

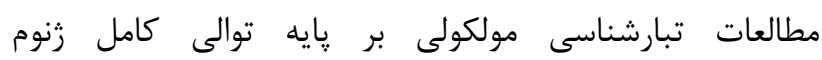

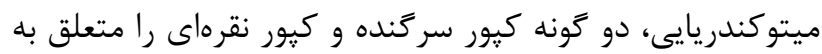

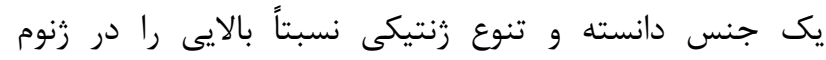

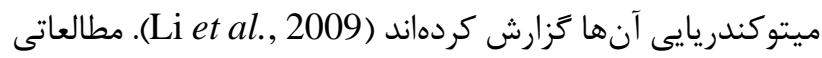

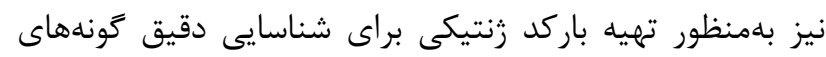

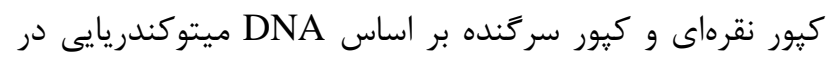
آمر يكاى شمالى انجام كرفته است (Farrington et al., 2014).

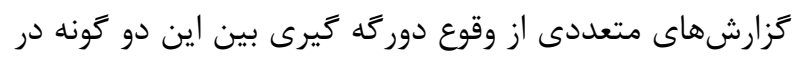

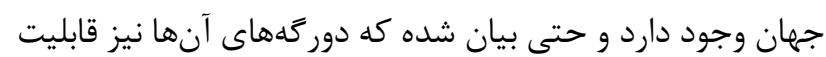

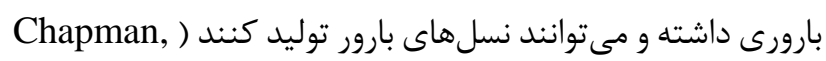

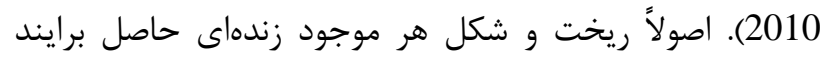
خصوصيات زنتيكى و عوامل محيطى آن است است ( Cataudella, 2007; Pulcini et al., 2007; Russo et al., 2007). مكانيسم اثر محيط بر ريخت ماهيان از طريق انتخاب

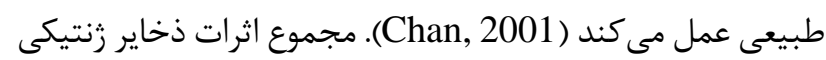
و انتخاب طبيعى سبب شده تا ماهيان يلانكتون خوار سازوكارهاى

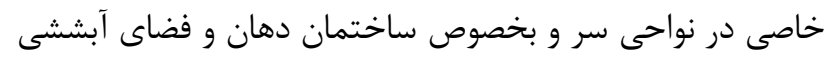

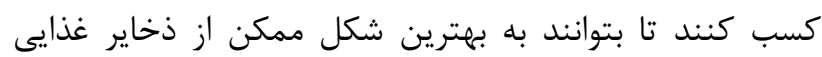

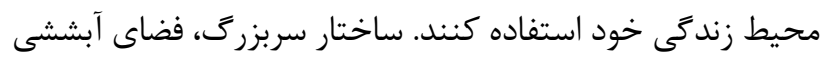

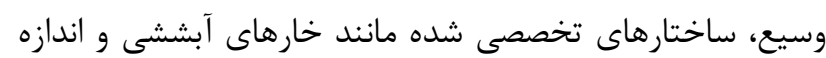

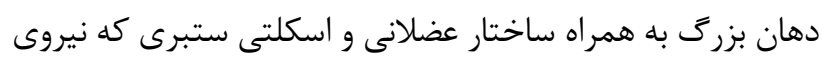

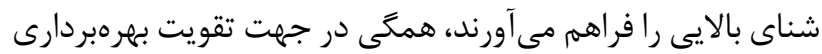

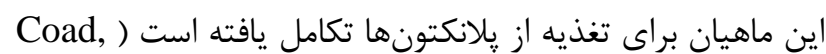
(2018; Froese \& Pauly, 2019

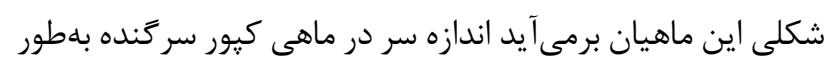

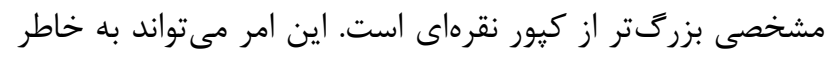

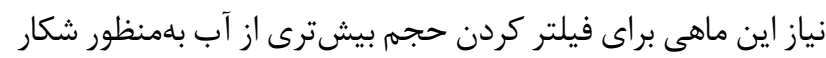

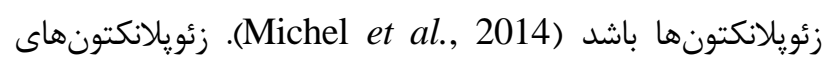
مورد تغذيه اين ماهيان در برخى موارد داراى قابليت تحرى هستيند

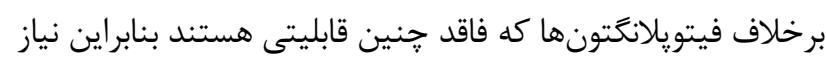

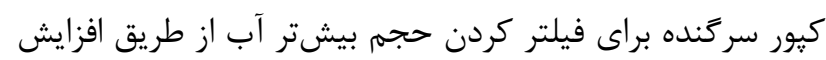

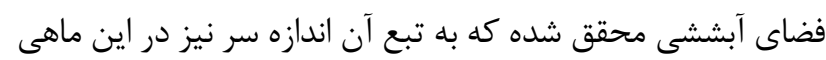

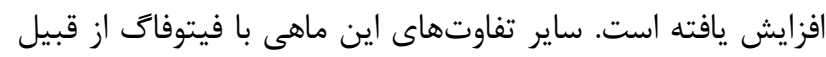

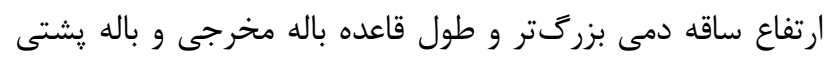

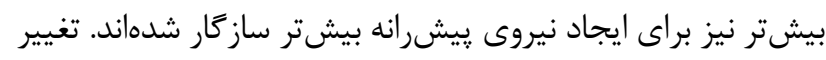

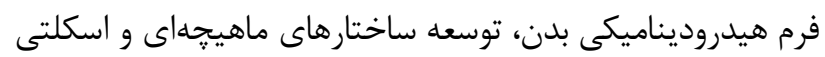

نسبت به خط ميانى بدن قرار دارد. در رابطه با دو ريخت كروه كيور

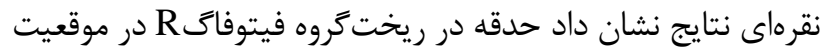

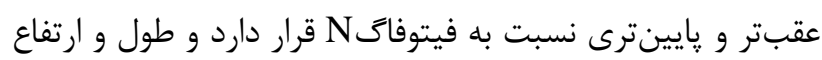

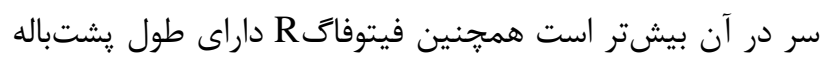

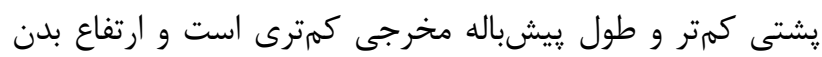
فيتوفاكى به سمت ساقه دمى كمتر است تجزيه و تحليل خوشهاى (Cluster Analysis) مختصات

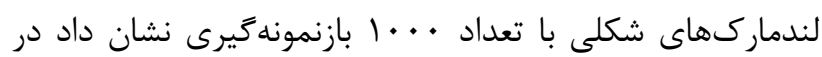

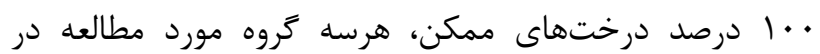

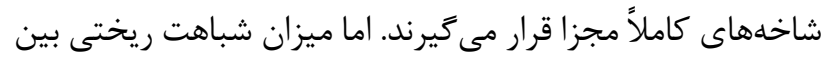

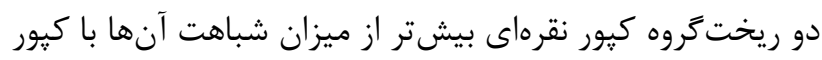

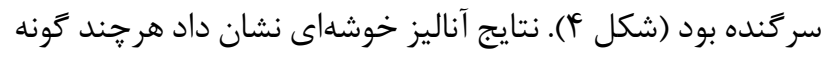

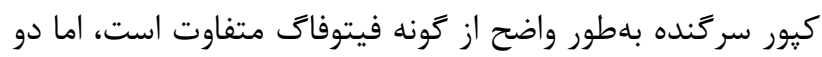

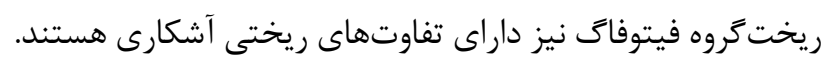

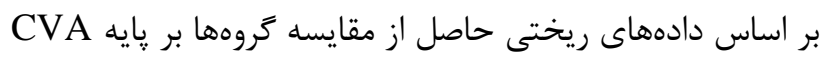

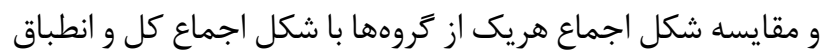

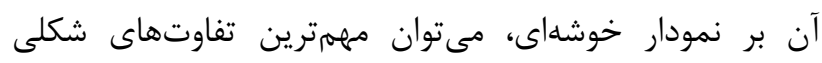

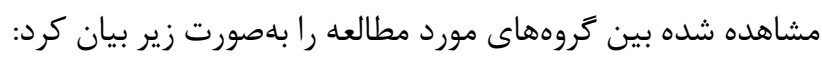

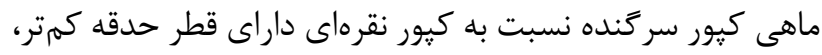

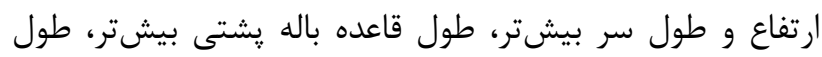

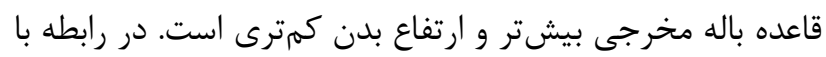
دو واريته كيور نقرهاى نكته جشمخير موقعيت عقبتر قاعده بردي باله سينهاى در فيتوفاگ Rو است (شكل عاع). شناسايى صحيح ماهيان يكى از اصول بنيادين براى مديريت، حفاظت و بهرهبردارى يايدار از آنهاست (Ibañez et al., 2007). از طرفى بسيارى از فعاليتهاى زيستى از قبيل الكَى تغذيهاى،

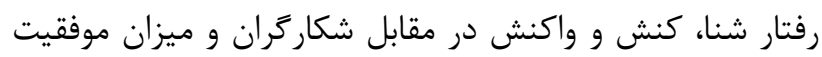

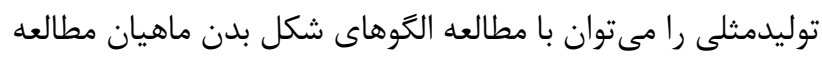
كرد (Guill et al., 2003). هريك از روشهاى شناساسيى و مطالعها ماهيان داراى نقاط ضعف و قوت خاص خود است. بهعنوانمثال مطالعات زنتيكى با وجود دقت بالا، زمانبر بوده و خاص اصولاً يرهزينه هuتيد ) Hutchinson et al., 2001; Keyvanshokooh \& (Kalbassi, 2006; Ghasemi et al., 2007 مختلف مههمترين صفات متمايز كننده دو كونه كيور نقرهاى و كيور

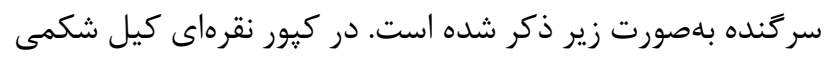

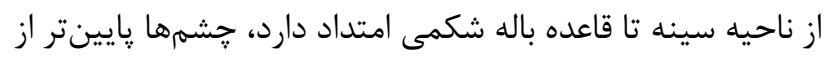
خط افقى ميانى سر قرار داشته و از نماى زيرين سر قابل مشاهده 

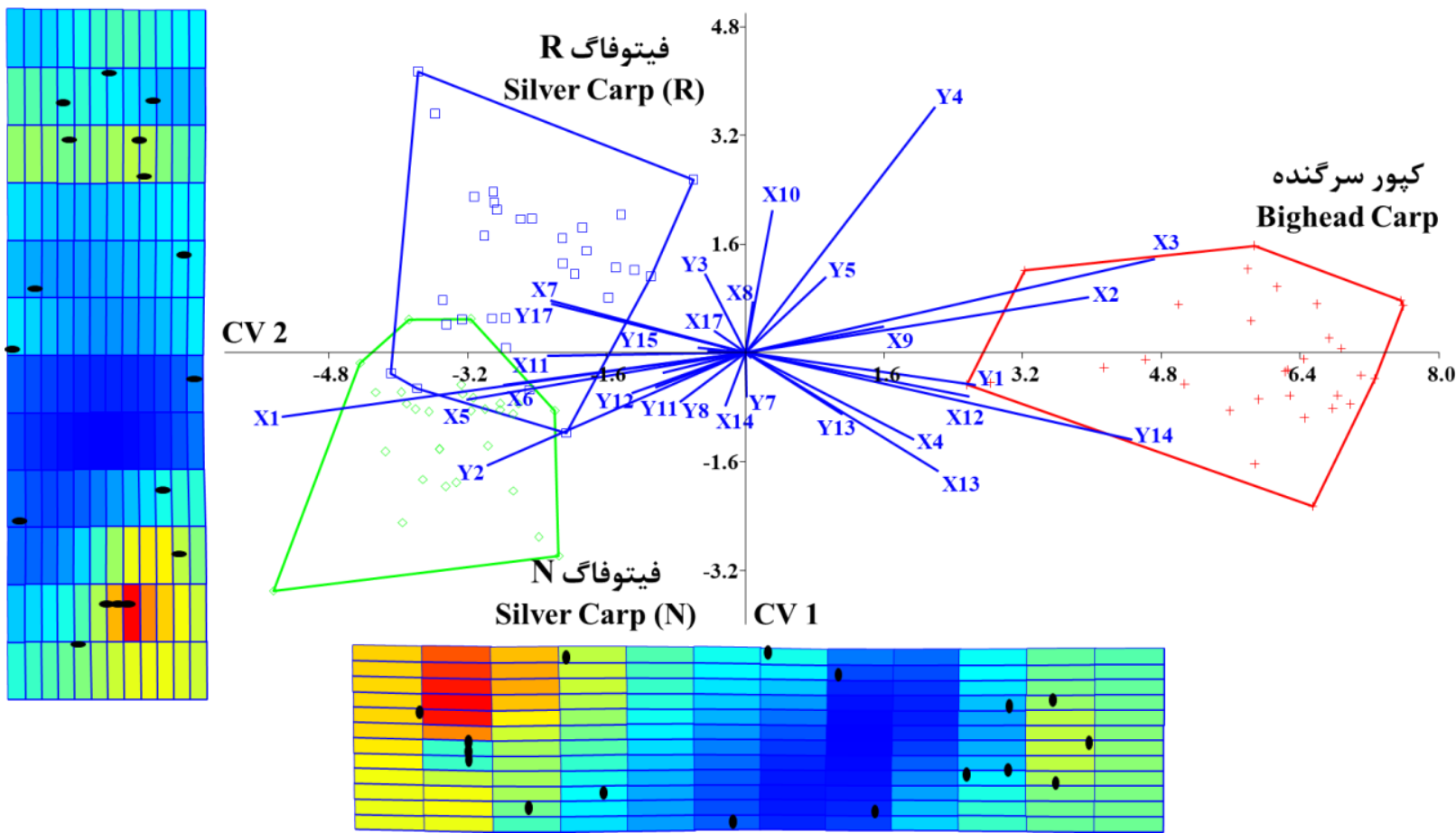

شكل ب- نمودار يراكنش، نمودارهاى بار عاملى و شبكه تغييرشكل بر اساس CV

Fig. 3. Scatterplot, biplot and deformation grids based on CV 1 and 2.

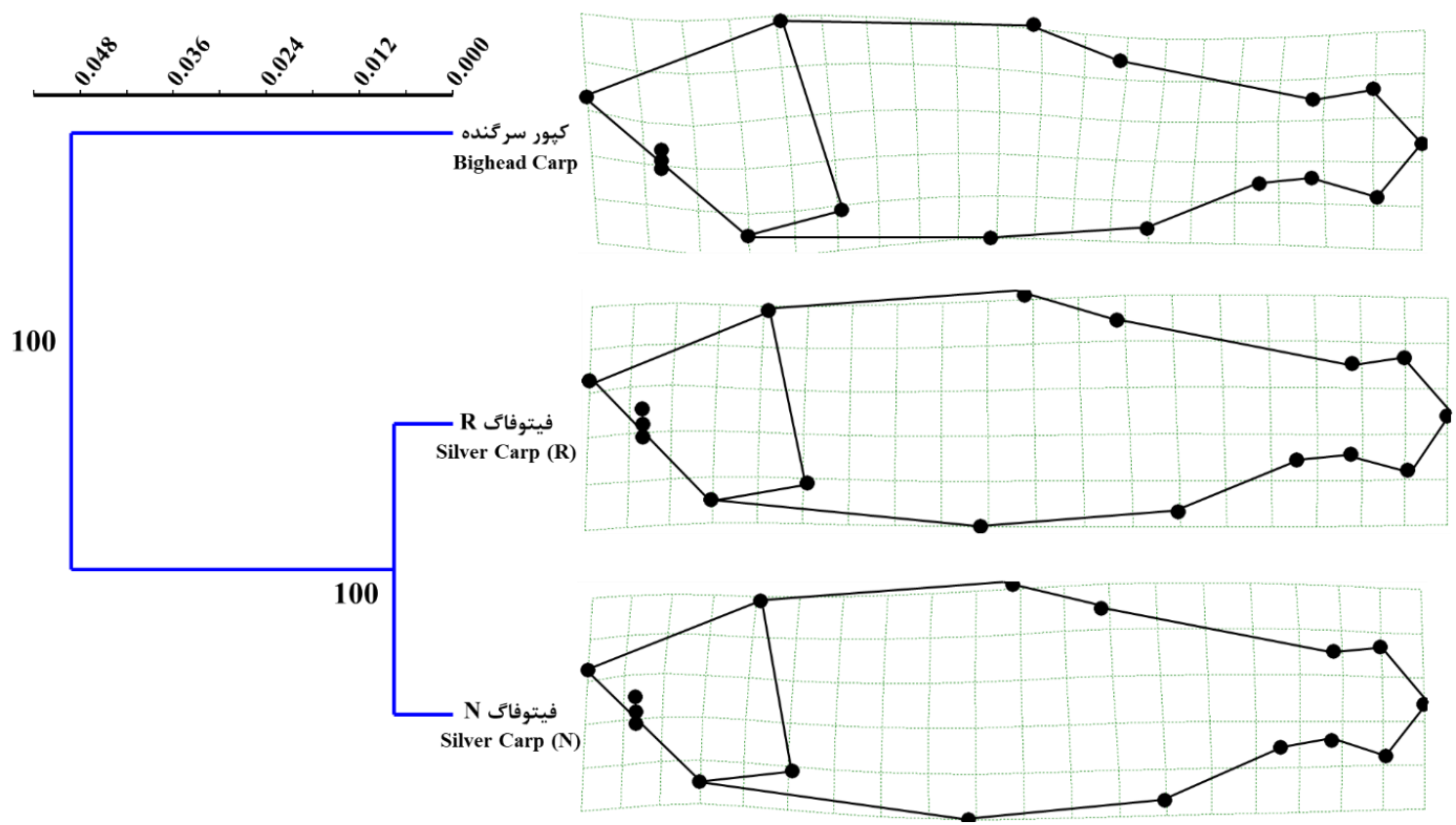

شكل F- نمودار تجزيهوتحليل خوشهاى به همراه مقايسه شكل اجماع هر جمعيت با شكل اجماع كل نمونهها (مقياس تصوير نشاندهنده فاصله بين كروهها بر

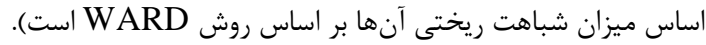

Fig. 4. Cluster analysis and consensus shapes of the three fish groups (the scale showing morphological distance based on WARD method). 
آبششى، موقعيت قرارگيرى باله سينهاى عقبتر رفته و متعاقب آن انتهاى باله سينهاى از قاعده باله شكمى عبور كرده است. بر اساس نتايج اين مطالعه ييشنهادهاى يزوهشى زئه زير ارائه

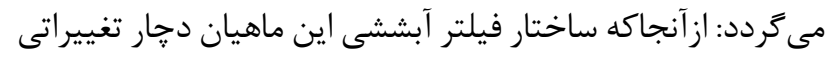

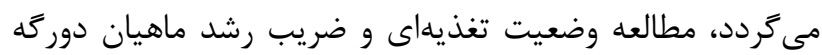

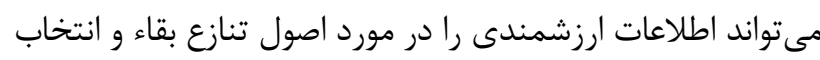

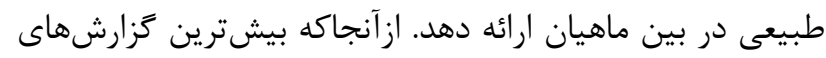

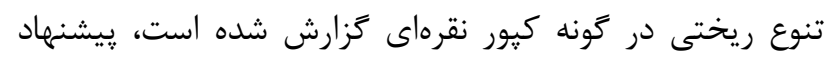

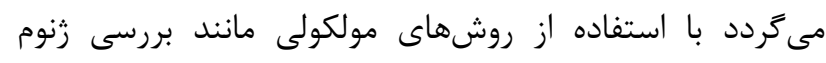
ميتوكندريايى مشخص گردد كه كداميك از دو گونه كيور سرگنده و نقرهاى والد نر و كداميك والد ماده هستند. يّاسخ اين سؤال مىتواند اطلاعات جالبى در مورد الگوى وراثت صفات در بين ماهيان را ارائه نمايد و در برنامههاى بهُخزينى ماهيان براى اهداف تكثير و يرورش بسيار ارزشمند خواهد بود.

\section{سياسگزارى}

مقاله حاضر با رشتيبانى مالى دانشعاه لرستان و دانشعاه آزاد واحد آزادشهر انجام شده است. از دكتر ايوب عزيزى به خاطر همكارى و هماهنگى جهت استفاده از آزمايشعاه قدردانى بعمل مى آوريم.

\section{REFERENCES}

Abdoli, A. 2000. The inland water fishes of Iran. Naghsh Mana Publication, Tehran. pp: 378.

Burr, B.M. and Warren, M.L. 1986. A distributional atlas of Kentucky fishes. Kentucky Nature Preserves Commission, Frankfort. pp: 398.

Chan, M.D. 2001. Fish ecomorphology: predicting habitat preferences of stream fishes from their body shape. $\mathrm{PhD}$, fisheries and wildlife sciences. Virginia Polytechnic Institute and State University, 269 pp.

Chapman, D.C. 2010. Facts about invasive bighead and silver carps. Center, U.C.E.R., Columbia, 1-2 p.

Coad, B.W. 2018. Freshwater fishes of Iran. Aavailable from: www.briancoad.com. [accessed 23 Feb 2018].

Conover, G., Simmonds, R. and Whalen, M. 2007. Management and control plan for bighead, black, grass, and silver carps in the United States. Asian Carp Working Group, Aquatic Nuisance Species Task Force, Washington D.C, 223 pp.

Cooper, W.J., Parsons, K., McIntyre, A., Kern, B., McGee-Moore, A. and Albertson, R.C. 2010. Benthopelagic divergence of cichlid feeding architecture was prodigious and consistent during multiple adaptive radiations within African rift-Lakes. - PLOS ONE 5: $1-13$.

Costa, C. and Cataudella, S. 2007. Relationship between shape and trophic ecology of selected species of Sparids of the Caprolace coastal lagoon (Central Tyrrhenian Sea). - Environ Biol Fishes. 78: 115-123.
براى حمايت اندامهاى شنا از جمله مهممترين موارد براى ايجاد Tytell et al., 2010; ) نيروى ييشرانه شنا در ماهيان هستند Eagderi et al., 2013; Ghojoghi et al., 2014 طول قاعده باله مخرجى و باله يشتى بهواسطه نقشى كه اين اندامها

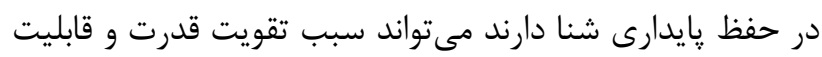

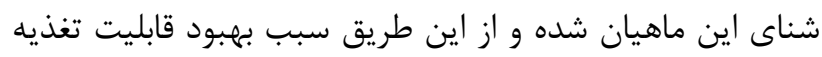
فيلترى آنها شود. شكل خاص باله دمى (هوموسرك بودن و و

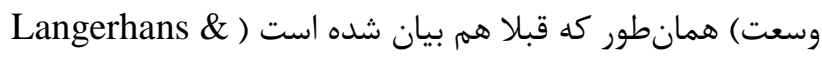
Reznick, 2010 )، سبب تقويت قابليت و دقت شنا در اين ماهيان شده است. اما در مورد دو ريخت گروه كيور نقرهاى مهلمترين تفاوتى كه مشاهده گرديد، مربوط به موقعيت قرارگيرى قاعده باله سينهاى بود. به نظر مىرسد آنجه سبب شده در بين ماهيان كيور نقرهاى مواردى مشاهده شود كه انتهاى باله سينهاى آنها از قاعده باله شكمى عبور مى كند و مواردى كه انتهاى باله سينهاى به قاعده باله شكمى نمىرسد، اين باشد كه بين مولدين كيور نقرهاى و كيور سر گنده عمل دورگه گيرى رخ داده است. در مورد قابليت هيبريد

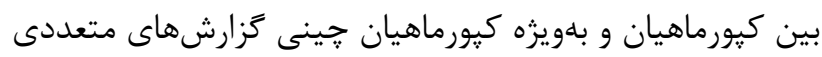

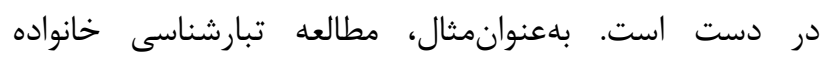
كيورماهيان نشان داده است كه در برخى موارد حتى احتمال

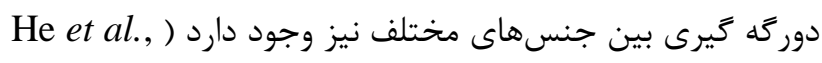

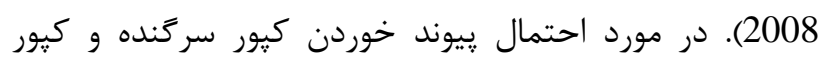
نقرهاى به آبهاى كانادا و بروز دورگَه گيرى بين آنها هشدار داده

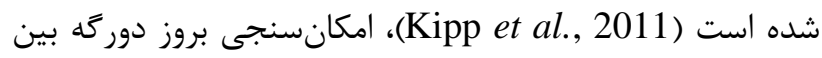
كيور سركنده و كيور علفخوار نشان داد كه اين دو گونه قابليت

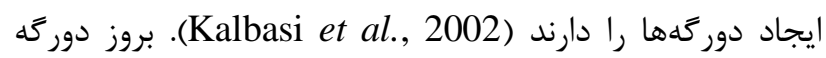
گيرى مصنوعى و طبيعى بين كيور علفخوار و كيور سر گنده مورد مطالعه و تاييد قرار زرفته و مشخص گرديد كه نسل اول آنها نيز نيز داراى قابليت بارورى هستند (Dorafshan \& Kalbassi, 2007). مطالعه برخى :ارامترهاى زيستى دورگه كيور سرگنده و كيور

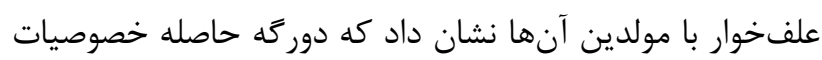
زيستى هردو والد را بروز مى Ebrahimzadeh et al., ) .2003

بر اساس نتايج مطالعه حاضر مىتوان بيان كرد كه كه ريخت

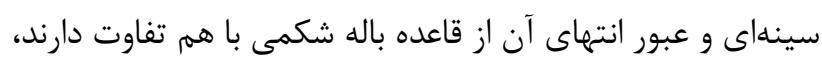
به دليل بروز دورَه بين اين گَونه و كيور سرَنده است. تغييرفرم

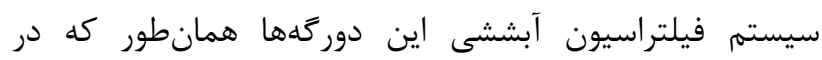
نيز اشاره شده است، نيازمند افزايش (Lamer et al., 2011) حجم فضاى آبششى بوده و به هميندليل با افزايش حجم محوطه 
Costa, C., Vandeputte, M., Antonucci, F., Boglione, C., Menesatti, P., Cenadelli, S., Parati, K., Chavanne, H. and Chatain, B. 2010. Genetic and environmental influences on shape variation in the European sea bass (Dicentrarchus labrax). - Biol. J. Linn Soc. 101: 427436.

Dorafshan, S. and Kalbassi, M.R. 2007. Karyological study of female Ctenopharyngodon idella $\times$ male Hypophtalmichthys nobilis F1 hybrids. - Biol. Sci. Promotion 20: 277-285.

Eagderi, S. and Adriaens, D. 2010. Cephalic morphology of Pythonichthys macrurus (Heterenchelyidae: Anguilliformes): specializations for head-first burrowing. - J. Morphol. 271: 1053-1065.

Eagderi, S., Esmaeilzadegan, E. and Maddah, A. 2013. Body shape variation in riffle minnows (Alburnoides eichwaldii De Filippii, 1863) populations of Caspian Sea basin. - TBJ 5: 1-8.

Ebrahimzadeh, S.M., Kalbasi, M.R., Nazari, R.M. and Behrouzi, S. 2003. Comparison of some biological parameters between grass carp and female grass carp $\mathrm{x}$ male bighead carp hybrid. - J. Iranian Mari. Sci. Technol. 2: 1-10.

Faradonbeh, M.Z., Eagderi, S. and Nasri, M. 2013. Morphological comparison of two population of Waspi (Aspidoparia morar Hamilton, 1822) using geometric morphometric technique. In: National Conference of New sciences and Technologies in Aquatics, Malayer. Malayer University.

Farrington, H.L., Edwards, C.E., Guan, X., Carr, M.R., Baerwaldt, K. and Lance, R.F. 2014. Numerous new mitogenomic sequences and multiple new environmental DNA markers for invasive bighead and silver carp (Hypophthalmichthys nobilis and $H$. molitrix) populations in North America. - BioRxiv. 7: 1-26.

Froese, R. and Pauly, D. 2019. FishBase. Aavailable from: www.fishbase.org. [accessed Aplil 2019].

Ghanbari, F., Kaboli, M., Eagderi, S. and NezamiBalouchi, B. 2013. Sexual dimorphism in skull morphology of the brown bear (Ursus arctos Linnaeus, 1758) in Iran using geometric morphometric technique. - TBJ 5: 17-26.

Ghasemi, A., Keyvanshokooh, S., Moghadam, M.S., Khara, H. and Sourinejad, I. 2007. Genetic comparison of Iranian and Azeri populations of the oriental bream Abramis brama orientalis (Berg) using microsatellites. - Aquac. Res. 38: 1742-1746.

Ghojoghi, F., AbolghasemKamali, Eagderi, S., Soltani, M. and Segherloo4, I.H. 2014. Morphological variation among the Caspian roach (Rutilusrutilus caspicus) populations fromthe Southern Caspian Sea using Geometric Morphometrics technique. - BEPLS 3: 105111.

Guill, M.J., Hood, C.S. and Heins, D.C. 2003. Body shape variation within and among three species of darters (Perciformes: Percidae). - Ecol. Freshw. Fish. 12: 134140.

Haghighi, E., Satari, M., Dorafshan, S., Keivani, Y., Khoshkholgh, M. and Moosavi-Sabet, S.-H. 2012. Comparative morphology of Khayateh (Cyprinidae:
Alburnoides eichwaldii) in Kargan-Rood and Chaloos Rivers using wireframe network. - JAIR 1: 41-52.

Hammer, Ø., Harper, D.A.T. and Ryan, P.D. 2001. Past: paleontological statistics software package for education and data analysis. - Palaeontol. Electron. 4: 1-9.

He, S., Mayden, R.L., Wang, X., Wang, W., Tang, K.L., Chen, W.-J. and Chen, Y. 2008. Molecular phylogenetics of the family Cyprinidae (Actinopterygii: Cypriniformes) as evidenced by sequence variation in the first intron of S7 ribosomal protein-coding gene: Further evidence from a nuclear gene of the systematic chaos in the family. - Mol. Phylogenetics Evol. 46: 818-829.

Hutchinson, W.F., Carvalho, G.R. and Rogers, S.I. 2001. Marked genetic structuring in localised spawning populations of cod Gadus morhua in the North Sea and adjoining waters, as revealed by microsatellites. - Mar. Ecol. Prog. Ser. 223: 251-260.

Ibañez, A.L., Cowx, I.G. and O'Higgins, P. 2007. Geometric morphometric analysis of fish scales for identifying genera, species, and local populations within the Mugilidae. - Can. J. Fish. Aquat. Sci. 64: 1091-1100.

Kalbasi, M.R., Sahebi, H.P. and Nazari, R.M. 2002. Feasibility study of Hybridisation between female Grass carp (Ctenopharyngodon idella) and male Bighead carp (Hypophthalmichthys nobilis) and their first generation hybrids. - J. Iranian Mari. Sci. Technol. 3: $35-44$.

Keyvanshokooh, S. and Kalbassi, M.R. 2006. Genetic variation of Rutilus rutilus caspicus (Jakowlew, 1870) populations in Iran based on random amplified polymorphic DNA markers: a preliminary study. Aquac. Res. 37: 1437-1440.

Kipp, R., Cudmore, B. and Mandrak, N.E. 2011. Biological Synopsis of Bighead Carp (Hypophthalmichthys nobilis) and Silver Carp (H. molitrix) Fisheries and Oceans Canada Centre of Expertise for Aquatic Risk Assessment, Canada, 58 p.

Lamer, J.T., Dolan, C.R., Petersen, J.L., Chick, J.H. and Epifanio, J.M. 2011. Introgressive hybridization between bighead carp and silver carp in the Mississippi and Illinois rivers. - North Am. J. Fish. Manage. 30: 1452-1461.

Langerhans, R.B. and Reznick, D.N. 2010. Ecology and evolution of swimming performance in fishes: Predicting evolution with biomechanics. In: Domenici, P. and Kapoor, B.G. (Ed.). Fish Locomotion: An Etho-Ecological Perspective. Science Publishers, pp: 200-248.

Li, S.F., Xu, J.W., Yang, Q.L., Chen, Q., Chapman, D.C. and Lu, G. 2009. A comparison of complete mitochondrial genomes of silver carp Hypophthalmichthys molitrix and bighead carp Hypophthalmichthys nobilis-Implications for their taxonomic relationship and phylogeny. - J. Fish Biol. 74: 787-803.

Michel, K.B., Adriaens, D., Aerts, P., Dierick, M. and Wassenbergh, S.V. 2014. Functional Anatomy and Kinematics of the Oral Jaw System During Terrestrial 
Feeding in Periophthalmus barbarus. - J. Morphol. 275: 1145-1160.

Mohadasi, M., Eagderi, S., Shabanipour, N., Hosseinzadeh, M.S., AnvariFar, H. and Khaefi, R. 2014. Allometric body shape changes and morphological differentiation of Shemaya, Alburnus chalcoides (Guldenstadf, 1772), populations in the southern part of Caspian Sea using Elliptic Fourier analysis. - IJAB 2: 164-171.

Nasri, M., Eagderi, S., Farahmand, H. and HashemzadeSegharLoo, I. 2013. Body shape comparison of Cyprinion macrostomum (Heckel, 1843) and Cyprinion watsoni (Day, 1872) using geometric morphometric method. - IJAB 1: 240-244.

Neeley, R. 2016. Monitoring and Response Plan for Asian Carp in the Upper Illinois River and Chicago Area Waterway System, U.S. Fish and Wildlife Service, Wilmington, $200 \mathrm{pp}$.

Pulcini, D., Costa, C., Aguzzi, J. and Cataudella, S. 2008. Light and Shape: A Contribution to Demonstrate Morphological Differences in Diurnal and Nocturnal Teleosts. - J. Morphol. 269: 375-385.

Rohlf, F.J. 2010. TpsDig2-Thin Plate Spline Digitise. New York, State University of New York.
Rohlf, F.J. 2015. tpsRelw: Thin Plate Spline Relative Warp Analysis. Stony Brook, New York, State University of New York at Stony Brook.

Russo, T., Costa, C. and Cataudella, S. 2007. Correspondence between shape and feeding habit changes throughout ontogeny of gilthead sea bream Sparus aurata L., 1758. - J. Fish. Biol. 71: 629-656.

Tedesco, P.A., Sagnes, P. and Larochejj, J. 2009. Variability in the growth rate of chub Leuciscus cephalus along a longitudinal river gradient. - J. Fish. Biol. 74: 312-319.

Tytell, E.D., Borazjani, I., Sotiropoulos, F., Baker, T.V., Anderson, E.J. and Lauder, G.V. 2010. Disentangling the functional roles of morphology and motion in the swimming of fish. - Integr. Comp. Biol. 50: 11401154.

Yazdi, F.T., Adriaens, D. and Darvish, J. 2012. Geographic pattern of cranial differentiation in the Asian Midday Jird Meriones meridianus (Rodentia: Muridae: Gerbillinae) and its taxonomic implications. - J. Zool. Syst. Evol. Res. 50: 157-164.

How to cite this article:

Ghojoghi, F. and Nasri, M. 2020. Body shape comparison of Big-head carp with two variants of silver carp using geometric morphometric techniques. - Nova Biol. Reperta 6: 382-390. (In Persian)

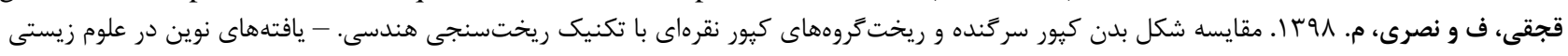

צ: • . 